\title{
The Relationship between Population Growth and Economic Growth: The Case of Singapore
}

Seher Suluk

To Link this Article: http://dx.doi.org/10.6007/IJARBSS/v11-i12/11702

DOI:10.6007/IJARBSS/v11-i12/11702

Received: 07 October 2021, Revised: 11 November 2021, Accepted: 25 November 2021

Published Online: 16 December 2021

In-Text Citation: (Suluk, 2021)

To Cite this Article: Suluk, S. (2021). The Relationship between Population Growth and Economic Growth: The Case of Singapore. International Journal of Academic Research in Business and Social Sciences, 11(12), 2385-2400.

\section{Copyright: (c) 2021 The Author(s)}

Published by Human Resource Management Academic Research Society (www.hrmars.com)

This article is published under the Creative Commons Attribution (CC BY 4.0) license. Anyone may reproduce, distribute, translate and create derivative works of this article (for both commercial and non0-commercial purposes), subject to full attribution to the original publication and authors. The full terms of this license may be seen at: http://creativecommons.org/licences/by/4.0/legalcode

\section{Vol. 11, No. 12, 2021, Pg. 2385- 2400}

Full Terms \& Conditions of access and use can be found at http://hrmars.com/index.php/pages/detail/publication-ethics 


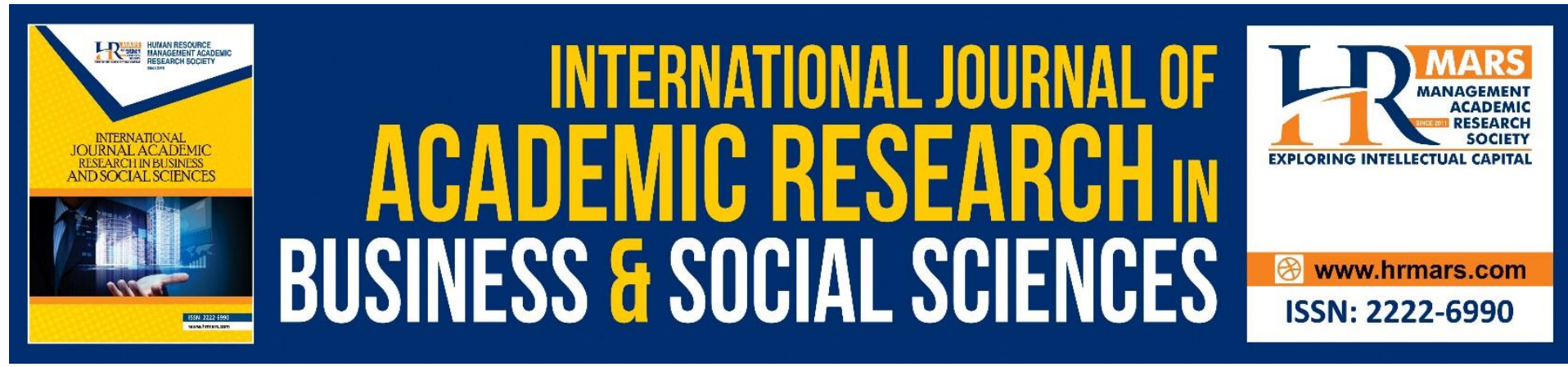

\title{
The Relationship between Population Growth and Economic Growth: The Case of Singapore
}

\author{
Seher Suluk \\ PhD., Independent Researcher \\ Email: sehersuluk119@gmail.com
}

\begin{abstract}
Population growth has an important impact on the economic performance of countries. However, there is no consensus on the direction of the impact in question. Therefore, the relationship between population growth and economic growth is still in debate in the literature. In this context, the aim of this study is to empirically examine whether there is a relationship between population growth and economic growth in Singapore using annual data for the period of 1970-2020. In order to achieve this goal, first of all, ADF and PP unit root tests were performed. Then, Toda-Yamamoto Causality Test was applied to investigate the causal relationship between the variables. According to the empirical findings of the study, there is a unidirectional Granger causality relationship from population growth to economic growth.
\end{abstract}

Keywords: Population Growth, Economic Growth, Singapore, Toda-Yamamoto Causality Test

\section{Introduction}

Economic growth which can be expressed as an increase in the production volume of an economy from one period to another can be measured as the percentage of change from the country's gross domestic product from year to year (Ozel, 2012: 64; Biede, 2015, 25). Population is a concept that influences many areas such as economics, sociology, psychology and politics and can be defined as the total number of people living in a given area during a given time period (Simsek and Atalay, 2020: 49; Aksu, 2011: 219). There are some factors that determine population growth. Especially, the increase in the fertility rate, and the decrease in the death rate are important factors that determine the population growth. In addition to these, migration also plays an important role in determining population growth (Basel, 2011: 524). The birth rate represents the share of the population born each year. The death rate shows the share of the number of deaths in the population each year. Net migration is the difference between immigration into and emigration from the area during the year. Net migration rate represents the share of net migration in the population (Taban and Kar, 2014: 113; https://stats.oecd.org). Population issue and population structure are important for all societies in terms of policies to be implemented (Gelekci, 2015: 588). Population policies are the decisions of governments and affect the quantity, quality and distribution of the population. It also affects the developments in the countries' health, education, housing, employment, city planning, agriculture and industry (Oktay, 2014: 31). In general today, there 
are three types of population policies applied. The first is the policy that aims reducing the population growth rate. The second is the policy that aims at stimulating and raising population growth. The third is the policy which aims to improve the quality and quantity of the population (Dogan, 2011: 295-296).

The world population is increasing and the population structure has changed and will continue to change. When examined historically, population growth gained a great speed especially with the industrial revolution and increased in almost every period. According to UN, the world population is projected to reach 8.5 billion in 2030, 9.7 billion in 2050 and 11.2 by 2100 . In this context, population and population growth have begun to attract great attention from the socio-economic point of view and besides, the role of population growth in the economic growth process has been the focus of attention of many researchers. While some researchers argue that population growth will contribute to economic growth, some researchers states that population growth affects economic growth negatively. Therefore, the impact of population growth on economic growth has become an important study topic in recent years. Today, the positive and negative sides of population growth is still in debate. Population growth can enlarge the workforce and boost economic growth (Savas, 2008: 162; Magnusson and Schuller, 2006: 10; https://www.un.org; Topal, 2011: 135). In other words, the increase in the population can improve the division of labor and contribute to the increase of productivity by enabling the establishment of large-scale enterprises. Thus, it can also allow for an increase in per capita income, an improvement in the standard of living and a much higher quality of education (Cipolla, 2015: 114). Population growth causes urbanization. Accordingly, population growth also affects housing, health and education expenditures (Basel, 2011: 525). It can be said that a healthy and educated population is prior condition for economic productivity, prosperity and development.

Population growth can cause to the found of alternative resources and accelerate technological development. On the other hand, population growth also largely increases the need for goods and services and these increasing needs can put great pressure on natural resources. The consumption of natural resources can reduce the rate of development and environmental quality (Mazi and Tan, 2009). With the increase in consumption, it can cause an increase in the wastes left to the environment in the production and consumption processes. This situation disrupts the ecological balance and can cause various environmental problems (Hayta, 2006: 362-363). Besides, in a country with a low population may result the lack of employment and may lead the failure of a development move that can be made in the economic and social field. At the same time, rapid population growth can negatively affect development in all aspects in a country with insufficient natural resources and capital (Kücükoglu and Tas, 2019: 236). For this reason, it is significant to examine the link between these variables and to create appropriate policies accordingly.

Singapore which is located in the Southeast Asia is a republic with a population of approximately 5.7 million in 2020. According to the World Bank income classification, Singapore is among the high-income countries and the country has more than doubled its GDP per capita in the last two decades and is also among the countries with the highest population density (IMF, 2019; World Bank; https://worldpopulationreview.com). Since the 1960s, Singapore has developed into one of the world's most highly developed economies and today is the country one of the most prosperous countries in the world and have a low unemployment rate. Moreover, the country has a good health care system and a good education system (Dansk Erhverv and EKF, 2020: 1; https://www.heritage.org; https://www.fn.no). Singapore, which achieved its independence in 1965, is a country with 
limited natural resources. The main sectors of the country are industry, service and tourism. Besides, the country is also an important financial and commercial center (http://www.geotema.dk). Singapore's economy has been structured in a very short time. The country has become one of world's major petrochemistry and electronics manufacturers, and a successful financial and banking center in the region (Konya Ticaret Odasi, 2014: 5). Advance in health care and life quality in Singapore caused to having one of the highest expectancy of life in the world. However, the prospect of an ageing population due to its low fertility rate is worrying for a country whose most important resource is its people. But it is expected that the population to work will increase rather than the elderly population withdrawing from the labor market. Because the people in Singapore attach importance to career and shunning welfare policies (https://www.statista.com).

The main purpose of this study is to examine the relationship between population growth and economic growth in Singapore with the use of Toda-Yamamoto causality test. The study covers the period of 1970-2020 and annual data were used in the study. The relationship between population growth and economic growth have been examined by researchers for several countries by using different periods and methods. But in the literature review related to the research subject, no study has been found that investigates the nexus between economic growth and population growth with Toda-Yamamoto causality test for Singapore. Therefore, this study intends to fill the gap in the literature. The remaining part of the study is organized as follows: Section 2 summarises the theoretical and empirical background of the relationship between economic growth and population growth. Section 3 presents the methodology and data set. Section 4 describes the findings obtained from the econometric analysis. Last section summarises the key findings of the study.

\section{Economic Growth-Population Relationship: Theoretical and Empirical Background}

Population growth has a significant impact on economic growth. However, there is no consensus on the direction of the impact in question. Therefore, the connection between population growth and economic growth has been the subject of intense concern among many researchers. Thomas Robert Malthus was the first to deal with this subject. In 1798, Malthus published his work, "An Essay on the Principle of Population" in which he argued that the earth's resources could not cope with the demands of an ever increasing population (Skousen, 2003: 75). Malthus was of the opinion that population growth was a threat to economic growth (Konat and Fendogdu, 2021: 283). Malthus stated that when unchecked, population increases in a geometrical ratio, while subsistence increases in an arithmetical ratio (Malthus, 1798: 4). According to Malthus, with the increasing population, living standards will come under pressure sooner or later (Estrup et al., 2013: 49). In other words, rapid population growth will lead to lower economic growth and cause poverty. Accordingly, population growth will put pressure on wages until the labor supply reaches the subsistence level. After this point, people will remain poor even if war, famine or disease can stop population growth. Lower wages will increase firms' profits. This stimulates labor demand and production. However, this situation will not continue for long and the increase in profits will be temporary due to the decrease in wages. As low wages negatively affect purchasing power, prices will gradually decrease and profits will be reduced (Eren, 2020: 142). According to Swedish economist Knut Wicksell, population growth should be kept in check the point where per capita income is maximum. In addition, he advocated that birth control should be provided by implementing voluntary and state-sponsored policies (Günes, 2009: 135). According to the neo-classical growth model, it is beneficial for the economy as population 
growth is associated with technological progress (Polat, 2018: 209). Adam Smith regarded population growth as a result and cause of economic development. Smith argued that increased investments due to the income obtained as a result of the increase in production will cause an increase in the demand for labor. And this situation will increase wages and the improvement of economic condition will lead to an increase in population attendantly (Bektas et al., 2015: 72). Besides, Smith emphasized that specialization and division of labor as the main source of increased productivity through increased economies of scale. Larger markets mean more field for specialization. According to Smith, population growth increases the scope of markets and thus drives productivity development (Lindh, 2000: 14). According to Keynes, population growth has a very important effect on demand for capital, so the rapid decline of the population will bring many problems (Keynes, 1937). Also, as the population increases, savings and investments are expected to rise. Production, capital accumulation, employment, incomes and savings will decrease as well as when population decreases and this situation will negatively influence development. Keynes emphasized that population growth will induce a powerful demand for goods that will make it plausible to establish a good market and rise the demand for capital (Menike, 2018: 68). In other words, population growth will increase the demand for existing industries, encourage the establishment of new industries and the market will expand continuously. At the same time, the young population structure that emerged due to population growth will be more open to growth, more prone to new ideas and more efficient in using resources (Telatar and Terzi, 2010: 200). Hansen emphasized that population growth is necessary in order to create demand that will encourage investments (Bektas et al., 215: 72). Kuznets showed that population growth has little effect on per capita income and that the effects of economic development are positively correlated with population growth. Thus Kuznets concluded that population remains the eventual source for economic development (Yao et al., 2013: 4654). According to Birdsall, population growth has a major contribution to economic growth. Because it causes an increase on demand and reduces risk of the investment, because it provides for constant improvement of the labor force with better educated workers, and because it may encourage technological innovation, especially in the agricultural sector (Birdsall, 1977: 65-66). Simon argued that the newer generation of job seekers entering the workforce will receive better education than the previous generation of workers, which will be more productive and lead to greater economic development (Menike, 2018: 68).

Empirical studies have also been conducted on the relationship between population growth and economic growth. Thornton (2001) examined the long-run relationship between population and GDP per capita in seven Latin American countries. To achieve this goal, Johansen maximal likelihood methodology, and Granger causality tests in the context of a one-step error correction model were performed. According to the test findings, no long-run relationship was found between the variables. Günes (2005) employed cointegration and vector error correction model to examine whether there is a long and short run connection between population growth and economic growth in Turkey. The study covers the period 1943-2003. From the findings of the analysis, it is seen that the effect of the population growth on economic growth is short-run, whereas there is a long run equilibrium relationship from economic growth to population. Tsen and Furuoka (2005) examined the nexus between population and economic growth in Asian economies and reached various results. According to empirical results, no long-term relationship between the variables was found. However, a two-way Granger causality relationship between economic growth and population for Japan, Korea and Thailand, one-way Granger causality relationship from population growth to 
economic growth for China, Singapore and the Philippines is from population growth to economic growth and one-way Granger causality relationship from economic growth to population growth for Hong Kong and Malaysia was found. Savas (2008) examined the causal nexus between population and per capita economic growth in the Central Asian Economies. The study covers the period of 1989-2007. According to the analysis results of the study, there is a long-run relationship between the variables. Thus, the findings provide strong support for the hypothesis that population is driving growth. In this context, a strong and positive relationship was observed between the variables in the Central Asian Economies. Afzal (2009) investigated the population growth and economic development situation of Pakistan using data for the period of 1981-2005. As a result of the empirical findings, there is an important and negative relationship between population growth and measures of economic advancement. Furuoka (2009) analyzed the long-run link between economic development and population growth in Thailand using data from 1960 to 2003. According to the empirical findings obtained from the study, there is a long-run equilibrium relationship between population growth and economic development. Besides, a one-way causality from population growth to economic development was found. Furuoka (2010), who examined the effect of population growth on economic development in the Philippines for the period of 1950-2007 found a long-run equilibrium relationship between economic performance and population growth. Besides, a one-way causality running from economic development to population growth was determined. Ali et al (2013) examined the effect of population growth on economic development in Pakistan. The study covers the period 1975 to 2008. ARDL method was used in the study. According to the empirical findings, population growth significantly and positively contributes to economic development. However, it was concluded that it was negatively affected by employment rate. Thuku et al. (2013) who examined the economic growth and population growth nexus in Kenya for the period 1963-2009 found that population growth and economic growth are both positively correlated. Besides, an increase in population will affect positively to the economic growth in the country. Abdullah et al (2015) studied the influence of population growth on economic growth in Bangladesh for the period of 1980-2005. To achieve this goal, they used multiple linear regression model. According to the analysis findings, economic growth and population are both negatively correlated and an increase in population will effect the economic growth negatively. Chang et al (2017) examined the link between population growth and standard-of-living growth in 21 countries. The study covers the period of 1870-2013. The study point out that there is a unidirectional Granger causality from population growth to standard-of-living growth for Finland, France, Portugal, and Sweden, unidirectional Granger causality from standard-ofliving growth to population growth for Canada, Germany, Japan, Norway and Switzerland, bidirectional causality for Austria and Italy, and no causal relationship for Belgium, Brazil, Denmark, Netherlands, New Zealand, Spain, Sri Lanka, the UK, the USA, and Uruguay. Akinbode et al (2017) studied the relationship between population growth and economic growth in Nigeria using data between the years 1970-2014. As a result of the empirical test findings, there is a one-way causality running from population growth to economic growth. Peter and Bakari (2018) examined the effect of population growth on the economic growth of African countries with the help of panel data approach. The study covers the period of 1980-2015. According to the findings of the study, population growth exerts a positive effect on economic growth of Africa while fertility has a negative impact on economic growth. Polat (2018) studied the relationship between economic growth and population growth in Turkey using the data of the period 1998-2015. According to the Johansen cointegration test results, 
the variables are cointegrated. Besides, according to the VECM test results, there is a long run relationship between the variables. Degu (2019) investigated the nexus between economic growth and population growth in Ethiopia. The study covers the period of 1981-2018. According to the ARDL test results, population growth have a negative and an important impact on economic growth, both in the short-run and in the long-run. Besides, both in the short and in the long run, growth in GDP influences population growth positively and significantly. Moreover, as a result of the Toda-Yamamoto Granger Causality test, a unidirectional causality relationship from population to economic growth was found. Eren (2020) investigated the development and population growth nexus in sub-Saharan African countries from 1990 to 2017. To achieve this goal, panel data analysis approach was used. The study point out that there is a bidirectional causality between population growth and development. Konat and Fendogdu (2021) investigated the relationship between population growth and development of BRICS-T countries by employing panel data analysis. The study covers the period of 1990-2019. Accordingly, a long-run relationship between the variables was found.

\section{Methodology and Data Set}

On the purpose of examine the causality relationship between population growth and economic growth in Singapore annual data from 1970 to 2020 are employed. The data are sourced from the World Bank database. In the analysis, GDP is the economic growth variable, and POP is the population growth variable. In the study, firstly, Augmented Dickey-Fuller (ADF) and Phillips-Perron (PP) unit root tests were performed and afterwards TodaYamamoto Causality Test was applied. Eviews program was used in the analysis phase of the study. Figure 1 shows the flowdown of the method used in the study.

Figure 1: Flow Chart of the Investigative Procedures Used in the Study

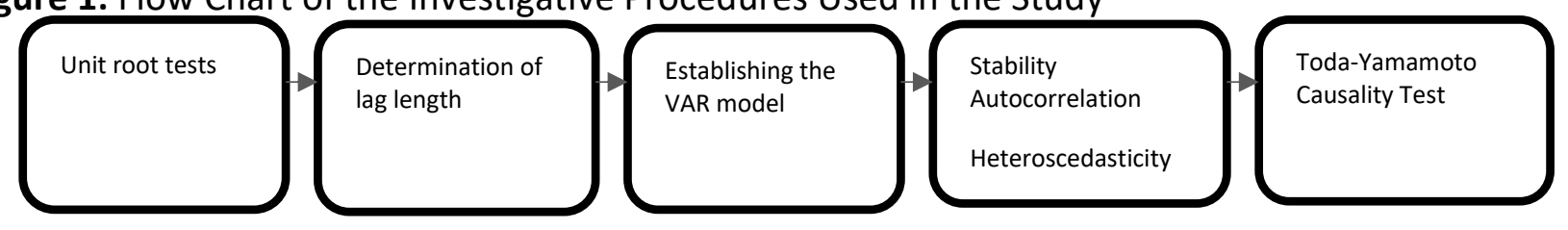

\section{ADF and PP Unit Root Tests}

In the first step of the study, Augmented Dickey-Fuller (ADF) and Phillips-Perron (PP) unit root tests which are the most widely used unit root tests in time series were performed. ADF unit root test includes three types of regression models (Dickey and Fuller, 1979: 427-431; Tari et al., 2019: 389):

$$
\begin{array}{ll}
\text { None } & \Delta Y_{t}=\delta Y_{t-1}+u_{t} \\
\text { Intercept } & \Delta Y_{t}=b_{0}+\delta Y_{t-1}+u_{t} \\
\text { Trend and Intercept } & \Delta Y_{t}=b_{0}+b_{1} t+\delta Y_{t-1}+u_{t}
\end{array}
$$

Then, the null and alternative hypothesis can respectively be written as: $H_{0}: a=0$ the series is not stationary, $H_{1}: a<0$ the series is stationary (Dickey and Fuller, 1979: 427).

Phillips and Perron (1988) proposed an alternative non-parametric method that controls the serial correlation in the testing process of the unit root hypothesis. In the PP unit root 
test, as the standard DF test the $H_{0}: \delta=0$ null hypothesis is tested against the $H_{1}: \delta<0$ alternative hypothesis (Mert and Caglar, 2019: 101).

\section{Toda-Yamamoto Causality Test}

Since its development after the work "Investigating Causal Relations by Econometric Models and Cross-spectral Methods" by Granger in 1969, Granger Causality Analysis has been one of the most common methods of examining the causal relationship between two variables (Mortensen, 2014: 95-113). Accordingly, Granger (1969) causality analysis is generally used to empirically investigate the causality relationship between variables in time series (Granger, 1969: 424-438). Granger causality analysis has been developed over time and various versions have begun to be applied. One of them is the Toda-Yamamoto Causality Test developed by Toda and Yamamoto (Kaygisiz, 2018: 4457). Toda-Yamamoto (1995) causality test is based on VAR model estimation. While performing the test, the stationarity degrees of the series is ignored and the level values of the series are used. Therefore, when estimating the VAR model, estimating is made according to VAR $\left(k+d_{\max }\right)$. Here, $k$ is the optimal lag length and $d_{\max }$ is the maximum degree of integration of the variables in the model (Toda and Yamamoto, 1995: 225). The equations of Toda-Yamamoto causality analysis are given below (Mert and Caglar, 2019: 345):

$$
\begin{aligned}
& y_{t}=\delta+\sum_{i=1}^{k+d_{\max }} a_{i} y_{t-i}+\sum_{i=1}^{k+d_{\max }} \theta_{i} x_{t-i}+e_{1 t} \\
& x_{t}=\delta+\sum_{i=1}^{k+d_{\max }} \gamma_{i} x_{t-i}+\sum_{i=1}^{k+d_{\max }} \theta_{i} y_{t-i}+e_{2 t}
\end{aligned}
$$

\section{Empirical Findings}

The descriptive statistics of the variables used in the model are shown in table 1 . The Jarque-Bera test shows that the probability value of GDP and POP is higher than 0.05 . Accordingly, it is seen that both variables have a normal distribution.

Table 1: Descriptive Statistics of Variables

\begin{tabular}{lll}
\hline & GDP & POP \\
\hline Mean & 2.007448 & 6.677443 \\
Median & 1.771833 & 7.200907 \\
Maximum & 5.321517 & 14.52564 \\
Minimum & -1.474533 & -5.391021 \\
Std. Dev. & 1.346334 & 4.298208 \\
Skewness & 0.174964 & -0.547768 \\
Kurtosis & 3.201296 & 3.046295 \\
Jarque-Bera & 0.346309 & 2.554978 \\
Probability & 0.841008 & 0.278736 \\
\hline Observations & 51 & 51 \\
\hline
\end{tabular}

In order to show the general trends of the series used in the study, the graphs of the variables for the period of 1970-2020 are given in figure 2 . Although there is no clear trend in the GDP variable, it is seen that there has been a decrease in the GDP rate since 2008. 
Likewise, although there is no clear trend in the POP variable, there has been a decrease since 2010. Therefore, it is observed that the series contains a trend and is not stationary.

Figure 2: Graphs of GDP and POP Variables

GDP Growth(\%)

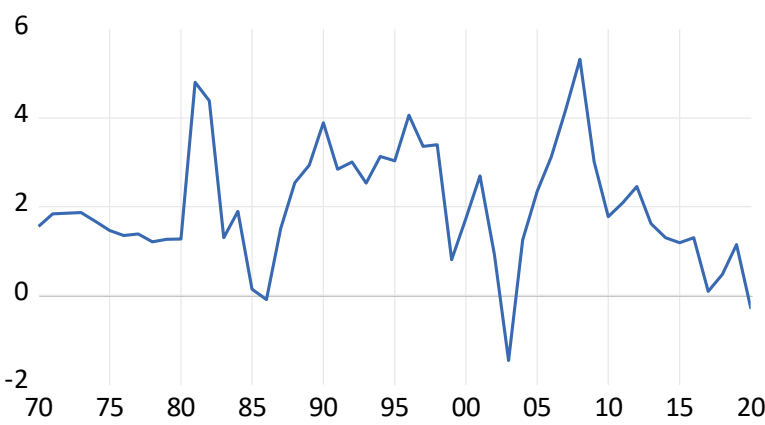

Population Growth(\%)

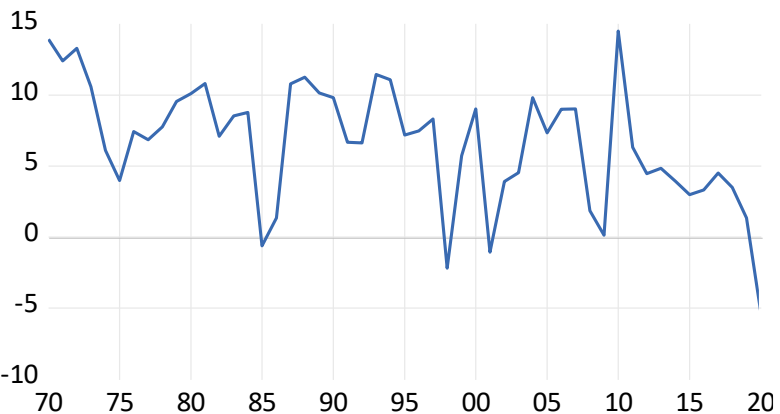

Table 2 shows the unit root tests results of ADF and PP. With intercept, it is seen that all of the variables are stationary at the level. With trend and intercept, GDP is stationary after the first difference is taken, and POP is stationary at level. Since the series contains a trend, the unit root test by adding the trend has been taken into account. In this context, it is decided to conduct Toda-Yamamoto causality test since the variables are stationary at different levels. In the Toda-Yamamoto causality test, level values of the series were used. 
INTERNATIONAL JOURNAL OF ACADEMIC RESEARCH IN BUSINESS AND SOCIAL SCIENCES Vol. 11, No. 12, 2021, E-ISSN: 2222-6990 @ 2021 HRMARS

Table 2: ADF and PP Unit Root Tests

\begin{tabular}{|c|c|c|c|c|c|}
\hline \multicolumn{6}{|l|}{ Intercept } \\
\hline \multirow{2}{*}{ Variables } & \multicolumn{2}{|c|}{ ADF Test Statistic } & \multicolumn{3}{|c|}{ Test Critical Values } \\
\hline & t-Statistic & Prob. & $1 \%$ & $5 \%$ & $10 \%$ \\
\hline GDP & -3.359532 & 0.0173 & -3.568308 & -2.921175 & - 2.598551 \\
\hline POP & -4.250008 & 0.0014 & -3.568308 & -2.921175 & $\begin{array}{l}- \\
2.598551\end{array}$ \\
\hline \multirow{2}{*}{ Variables } & \multicolumn{2}{|c|}{ PP Test Statistic } & \multicolumn{3}{|c|}{ Test Critical Values } \\
\hline & Adj. t-Stat & Prob. & $1 \%$ & $5 \%$ & $10 \%$ \\
\hline GDP & -3.359532 & 0.0173 & -3.568308 & -2.921175 & - 2.598551 \\
\hline POP & -4.247782 & 0.0014 & -3.568308 & -2.921175 & $\begin{array}{l}- \\
2.598551\end{array}$ \\
\hline \multicolumn{6}{|c|}{ Trend and Intercept } \\
\hline \multirow{2}{*}{ Variables } & \multicolumn{2}{|c|}{ ADF Test Statistic } & \multicolumn{3}{|c|}{ Test Critical Values } \\
\hline & t-Statistic & Prob. & $1 \%$ & $5 \%$ & $10 \%$ \\
\hline GDP & -3.359720 & 0.0686 & -4.152511 & -3.502373 & $\begin{array}{l}- \\
3.180699\end{array}$ \\
\hline $\mathrm{D}(\mathrm{GDP})$ & -6.451028 & 0.0000 & -4.161144 & -3.506374 & $\begin{array}{l}- \\
3.183002\end{array}$ \\
\hline POP & -5.228847 & 0.0004 & -4.152511 & -3.502373 & $\begin{array}{l}- \\
3.180699\end{array}$ \\
\hline $\mathrm{D}(\mathrm{POP})$ & -8.403510 & 0.0000 & -4.161144 & -3.506374 & 3.183002 \\
\hline \multirow{2}{*}{ Variables } & \multicolumn{2}{|c|}{ PP Test Statistic } & \multicolumn{3}{|c|}{ Test Critical Values } \\
\hline & Adj. t-Stat & Prob. & $1 \%$ & $5 \%$ & $10 \%$ \\
\hline GDP & -3.359720 & 0.0686 & -4.152511 & -3.502373 & $\begin{array}{l}- \\
3.180699\end{array}$ \\
\hline $\mathrm{D}(\mathrm{GDP})$ & -8.525340 & 0.0000 & -4.156734 & -3.504330 & $\begin{array}{l}- \\
3.181826\end{array}$ \\
\hline POP & -5.118145 & 0.0006 & -4.152511 & -3.502373 & $\begin{array}{l}- \\
3.180699\end{array}$ \\
\hline $\mathrm{D}$ (POP) & -12.76221 & 0.0000 & -4.156734 & -3.504330 & $\begin{array}{l}- \\
3.181826 \\
\end{array}$ \\
\hline
\end{tabular}

After applying the ADF and PP unit root tests, the optimal lag length should be determined. Schwert (1989) suggests choosing the maximum lag with the formula $P_{\max }=$ $\left[12\left(\frac{n}{100}\right)^{\frac{1}{4}}\right]$ (Schwert, 1989: 151). Schwert's formula was used to determine the maximum number of lag for the VAR model. The number of observations in the study is 51 . In this context, according to the results obtained from Schwert's formula, the maximum number of lag is $\left[12\left(\frac{51}{100}\right)^{\frac{1}{4}}\right]=10.14$. For this reason, based on a maximum of 10 lag information and according to the LR, FPE, AIC, SC and HQ information criteria, the optimal lag length is determined as 1. 
Table 3: Lag Length Criteria

\begin{tabular}{|l|l|l|l|l|l|l|}
\hline Lag & LogL & LR & FPE & AIC & SC & HQ \\
\hline 0 & -189.1684 & NA & 38.45751 & 9.325289 & 9.408878 & 9.355727 \\
\hline 1 & -171.9858 & $31.85068^{*}$ & $20.22673^{*}$ & $8.682235^{*}$ & $8.933002^{*}$ & $8.773550^{*}$ \\
\hline 2 & -169.0098 & 5.226137 & 21.30352 & 8.732186 & 9.150131 & 8.884379 \\
\hline 3 & -167.2174 & 2.972839 & 23.82825 & 8.839872 & 9.424994 & 9.052941 \\
\hline 4 & -166.3444 & 1.362662 & 27.97138 & 8.992411 & 9.744711 & 9.266357 \\
\hline 5 & -164.7931 & 2.270194 & 31.91344 & 9.111860 & 10.03134 & 9.446683 \\
\hline 6 & -162.3578 & 3.326344 & 35.08227 & 9.188184 & 10.27484 & 9.583884 \\
\hline 7 & -157.6608 & 5.957079 & 34.79691 & 9.154187 & 10.40802 & 9.610764 \\
\hline 8 & -156.0269 & 1.912908 & 40.45103 & 9.269604 & 10.69062 & 9.787058 \\
\hline 9 & -154.9797 & 1.123780 & 48.95185 & 9.413646 & 11.00183 & 9.991976 \\
\hline 10 & -151.5986 & 3.298699 & 53.62965 & 9.443833 & 11.19920 & 10.08304 \\
\hline
\end{tabular}

In the next step after determining the optimal lag length, the VAR model has been estimated by considering the conditions of Toda-Yamamoto causality test. In order for the VAR model constructed with the optimal lag length suggested by the information criteria to be meaningful, the inverse roots of the AR characteristic polynominal must be located within the unit circle. Table 4 and figure 3 show the values and distribution of the inverse roots of AR characteristic polynomial. It can be seen from table 4 that the modulus values are less than the reference value of 1 . Again, it is seen from figure 3 that all the inverse roots of $A R$ characteristic polynomial of the model are not outside but are located within the unit circle. Therefore, the model created does not have a stationarity problem.

Table 4: Roots of Characteristic Polynomial

\begin{tabular}{|l|l|}
\hline Root & Modulus \\
\hline $0.386366-0.188185 i$ & 0.429759 \\
\hline $0.386366+0.188185 i$ & 0.429759 \\
\hline
\end{tabular}

Figure 3: Inverse Roots of AR Characteristic Polynomial

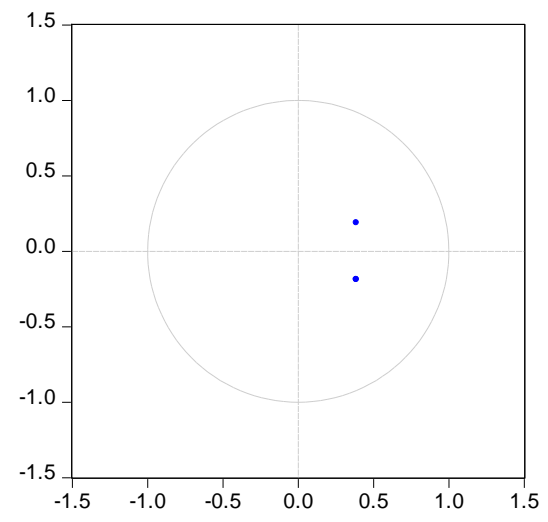

In order for the results of the VAR model established at the determined lag length to be reliable, there should be no autocorrelation and heteroscedasticity problems. The diagnostic tests results are given in table 5 . Accordingly, it is seen that the probability values are greater than 0.05 . Therefore, as a result of the autocorrelation and heteroscedasticity tests, it is seen that there is no autocorrelation and heteroscedasticity problems. At the same time, it is 
determined that there is a normal distribution as a result of the normality test. This result supports that there are no structural problems in the VAR model.

Table 5: Diagnostics Tests

\begin{tabular}{|c|c|c|}
\hline \multicolumn{3}{|c|}{ Autocorrelation Test } \\
\hline Lags & LM-Stat & Prob. \\
\hline 1 & 5.194083 & 0.2680 \\
\hline 2 & 6.970834 & 0.1374 \\
\hline \multicolumn{3}{|c|}{ Heteroscedasticity Test } \\
\hline Chi-sq & df & Prob. \\
\hline 18.14628 & 30 & 0.9561 \\
\hline \multicolumn{3}{|c|}{ Normality Test } \\
\hline Jarque-Bera & df & Prob. \\
\hline 8.198926 & 4 & 0.0846 \\
\hline
\end{tabular}

After examining the autocorrelation, heteroscedasticity and normality tests, TodaYamamoto causality test were performed to determine the causality relationship between the series. It is decided that the highest degree of integration of the variable is $d_{\max }=1$ and the optimal lag length $k=1$. It is concluded that $d_{\max }+k=2$ required for the Toda-Yamamoto causality test. The results obtained considering the relevant situation are shown in table 8 . According to the Toda-Yamamoto causality test results, there is a unidirectional causality relationship from population growth to economic growth. Thus, population growth is the Granger cause of economic growth. Accordingly, $\mathrm{H}_{0}$ is rejected while $\mathrm{H}$ alternative is accepted. In spite of that, there is no Granger causality relationship from economic growth to population growth.

Table 6: Toda-Yamamoto Causality Test Results

\begin{tabular}{|l|l|l|l|l|l|}
\hline \multicolumn{2}{|l|}{ Dependent Variable: GDP } \\
\hline Variables & $\begin{array}{l}\mathbf{D}_{\max }=\mathbf{1}, \mathbf{k}= \\
\mathbf{1} \\
\mathbf{D}_{\max }+\mathbf{k}=\mathbf{2}\end{array}$ & Chi-sq & Prob. & Direction of Causality & Hypothesis \\
\hline POP & $\mathbf{2}$ & 14.95175 & 0.0001 & $\begin{array}{l}\text { There is a Granger Causality } \\
\text { POP } \rightarrow \text { GDP }\end{array}$ & $\mathrm{H}_{0}$ rejected \\
\hline Dependent Variable: POP & $\begin{array}{l}\mathbf{D}_{\max }=\mathbf{1} \mathbf{k}= \\
\mathbf{1} \\
\mathbf{D}_{\max }+\mathbf{k}=\mathbf{2}\end{array}$ & Chi-sq & Prob. & Direction of Causality & Hypothesis \\
\hline GDP & 2 & 0.238043 & 0.6256 & There is no Granger Causality & $\mathrm{H}_{0}$ accepted \\
\hline
\end{tabular}

\section{Conclusion}

It can be said that ensuring economic growth and development and improving living conditions are among the primary goals of each country. In this context, demographic factors play an important role in these processes. Excessive population growth can lead to various problems. However, the decrease or very little increase in population can affect the future of the countries negatively and even threaten them (Dogan, 2011: 295). 
In the literature, there are many academic studies examining the relationship between economic growth and population growth. However, it is seen that the results obtained differ. According to some empirical studies, there is two-way interaction between economic growth and population growth. Some empirical studies show, that the direction of the relationship between the variables is from population growth to economic growth, other empirical studies show that the direction of this relationship is from economic growth to population growth. Finally, there are also studies that found that there is no relationship between the variables. Therefore, it can be said that consequences of population growth and the influence of population growth on economic growth are controversial.

In this study, the population growth and economic growth nexus in Singapore is empirically examined. Annual data between 1970 and 2020 were used in the study. First of all, ADF and PP unit root tests were applied. Then Toda-Yamamoto causality analysis was performed to determine whether there is causality relationship between the variables. According to the findings of the Toda-Yamamoto causality test, there is a unidirectional Granger causality relationship from population growth to economic growth. This conclusion is consistent with other studies like Furuoka (2009), Akinbode et al. (2017), Degu (2019) and in part Tsen and Furuoka (2005) and Chang et al. (2017). The source of the country's labor force is the population (Yanardag and Ozgen, 2003). In this context, given the empirical results, population growth can be a driver for Singapore's economic growth. However, it is important to use limited natural resources more effectively and efficiently, as population growth can also cause resource depletion. In this context, countries with healthy and qualified manpower are expected to show more sensitivity in using natural resources. Singapore has a developed economy and a good education and healthcare system. Therefore, in order for this increase to have a positive effect on economic growth as the population increases, it is necessary to give priority to human capital and to implement policies for the continuous development of the labor force. Because only educated and healthy individuals can be productive and benefical to the society and the country. At the same time, the increase in production as a result of the active work of individuals in the country will contribute to economic growth. Therefore, in order to maximize the benefits of population growth, it is important to develop appropriate policies, taking into account the socio-economic situation of the country, as well as focusing on efficiency.

\section{References}

Abdullah, Shah, T., Sargani, G. R., Ali, A., \& Siraj, W. (2015). The Effect of Increase in Population on the Economic Growth of Bangladesh, Developing Country Studies, 5(17), 87-94.

Afzal, M. (2009). Population Growth and Economic Development in Pakistan, The Open Demography Journal, 2, 1-7.

Akinbode, S. O., Okeowo, K. S., \& Azeez, A. (2017). The Dynamics of Population and Economic Growth in Nigeria, Journal of Economics and Development Studies, 5(3), 79-86. DOI: 10.15640/jeds.v5n3a9

Aksu, L. (2011). Dünya'da ve Türkiye'de Nüfus Analizleri, Sosyoloji Konferanslari, 0(25), 219311.

Ali, S., Ali, A., \& Amin, A. (2013). The Impact of Population Growth on Economic Development in Pakistan, Middle-East Journal of Scientific Research, 18(4), 483-491. DOI: 10.5829/idosi.mejsr.2013.18.4.12404

Basel, H. (2011). Türkiye'de Nüfus Hareketlerinin ve ìc Gocün Nedenleri, Sosyal Siyaset Konferans/ari Dergisi, (0)53, 515-542. 
Bektas, H., Kayacan, E., \& Uras, O. (2015). Türkiye'de Planli Kalkinma Doneminde İktisadi Büyüme ile Nüfus Artisi İliskisinin Ekonometrik Analizi, İsletme ve iktisat Calismalari Dergisi, 3(2), 69-77.

Biede, J. H. (2015). Makroøkonomi - i Teori og Praksis, 1. Udgave, 1. Oplag, København: Hans Reitzels Forlag.

Birdsall, N. (1977). Analytical Approaches to the Relationship of Population Growth and Development, Population and Development Review, 3(1/2), 63-102. DOI: https://doi.org/10.2307/1971760

Cipolla. (2015). Dünya Nüfusunun iktisat Tarihi, Mehmet Sirri Gezgin (translator), 5. Basim, İstanbul: Otüken Nesriyat Yayinlari.

Chang, T., Chu, H-P., Deale, F. W., Gupta, R., \& Miller, S. M. (2017). The Relationship between Population Growth and Standard-of-living Growth over 1870-2013: Evidence From a Bootstrapped Panel Granger Causality Test, Empirica, 44(1), 175-201. DOI: https://doi.org/10.1007/s10663-016-9315-9

Dansk Erhverv \& Danmarks Eksportkredit (EKF). (2020). Markedsrapport for Singapore.

Degu, A. A. (2019). The Nexus between Population and Economic Growth in Ethiopia: An Empirical Inquiry, International Journal of Business and Economic Sciences Applied Research, 12(3), 43-50.

Dickey, D. A., \& Fuller, W. A. (1979). Distribution of the Estimators for Autoregressive Time Series With a Unit Root, Journal of the American Statistical Association, 74(366), 427431. DOI: https://doi.org/10.2307/2286348

Dogan, M. (2011). Türkiye'de Uygulanan Nüfus Politikalarina Genel Bakis, Marmara Cografya Dergisi, 23, 293-307.

Erdogdu, H., \& Baykut, E. (2016). BIST Banka Endeksi'nin (XBANK) VIX ve MOVE Endeksleri ile iliskinin Analizi, Bankacilar Dergisi, 98, 57-72.

Eren, M. V. (2020). Nüfus Artisi ile Kalkinma Arasindaki İliski: Sahra-alti Afrika Ülkeleri Üzerine Ampirik Bir Analiz, International Journal of Economic and Administrative Studies, 27, 141-158. DOI: $10.18092 /$ ulikidince. 586948

Estrup, H., Jespersen, J., \& Nielsen, P. (2013). Den Økonomiske Teoris Historie - En Introduktion, 2. Udgave, Jurist- og $\varnothing$ konomforbundets Forlag.

Furuoka, F. (2009). Population Growth and Economic Development: New Empirical Evidence from Thailand, 29(1), Economics Bulletin, 1-14.

Furuoka, F. (2010). Population Growth and Economic Development: Empirical Evidence from the Philippines, Philippine Journal of Development, XXXVII(1), 81-93.

Gelekci, C. (2015). 1690 Sonrasi Donemde Türkiye'de Nüfus Yapisi ve Bazi Temel Ozellikleri Üzerine Tespitler, Sosyoloji Konferanslari, 52, 587-607. DOI: 10.18368/IU/sk.63274

Granger, C. W. J. (2014). Investigating Causal Relations by Econometric Models and Crossspectral Methods, Econometrica, Vol. 37, No. 3, 1969, 424-438. DOI: https://doi.org/10.2307/1912791

Günes, H. H. (2009). İktisat Tarihi Acisindan Nüfus Teorileri ve Politikalari, Elektronik Sosyal Bilimler Dergisi, 8(28), 126-138.

Günes, S. (2005). Türkiye'de Nüfus Artisinin Ekonomik Büyümeyle İliskisi Üzerine Ekonometrik Bir Analiz, Ankara Üniversitesi SBF Dergisi, 60(03), 123-136. DOI: https://doi.org/10.1501/SBFder_0000001436

Hayta, A. B. (2006). Cevre Kirliliginin Onlenmesinde Ailenin Yeri ve Onemi, Ahi Evran Üniversitesi Kirsehir Egitim Fakültesi Dergisi, 7(2), 359-376. 
IMF. (2019). Singapore: 2019 Article IV Consultation-Press Release; Staff Report; and Statement by the Executive Director for Singapore https://www.imf.org/en/Publications/CR/Issues/2019/07/15/Singapore-2019Article-IV-Consultation-Press-Release-Staff-Report-and-Statement-by-the-47119

Kaygisiz, A. D. (2018). Türkiye'de Yurt İci Üretici ve Tüketici Fiyatlari Arasindaki íliski: 20062018, Jounal of Social and Humanities Sciences Research, 5(30), 4452-4460. DOI: $10.26450 /$ jshsr.923

Keynes, J. M. (1937). Some Economic Consequences of a Declining Population, The Eugenics Review, 29(1), 13-17.

Konat, G., \& Fendogdu, E. (2021). BRICS-T Ülkelerinin Nüfus Artis Hizi ile Kalkinma İliskisi: Yapisal Kirilmali Esbütünlesme Analizi, Karadeniz Uluslararasi Bilimsel Dergi, 1(51), 279-295. DOI: https://doi.org/10.17498/kdeniz.976501

Konya Ticaret Odasi. (2014). Singapur Ülke Raporu.

Kücükoglu, M., \& Tas, H. Y. (2019). Nüfus-Kalkinma İliskisi, 4. Uluslararasi GAP Sosyal Bilimler Kongresi, 29 Kasim-1 Aralik 2019, Sanliurfa, 235-244.

Lindh, T. (2000). Makroekonomiskt Beroende av Demografin: En Nyckel till Bättre Framtidsbedomningar, Penning- och Valutapolitik, 13-41.

Magnusson, B., \& Schuller, B-J. (2006). Demografi och Ekonomisk Tillväxt, ITPS, Institutet for Tillväxtpolitiska Studier, Ostersund.

Malthus, T. R. (1798). An Essay on the Principle of Population, London, London: J. Johnson. Mazi, F., \& Tan, M. (2009). Nüfus Artisi, Kaynak Tüketimi ve Cevre, Mevzuat Dergisi, 136.

Menike, H. R. A. (2018). A Literature Review on Population Growth and Economic Development, International Journal of Humanities Social Sciences and Education, 5(5), 2018, 67-74. DOI: http://dx.doi.org/10.20431/2349-0381.0505009

Mert, M., \& Caglar, A. E. (2019). Eviews ve Gauss Uygulamali Zaman Serileri Analizi, 1. Baski, Ankara: Detay Yayincilik.

Mortensen, P. B. (2014). Granger Kausalitet, Politica, 46. årg. nr. 1, 95-113.

Oktay, E. Y. (2014). Türkiye'de Cumhuriyet'in İlanindan Günümüze Uygulanan Nüfus Politikalari, Yalova Sosyal Bilimler Dergisi, 4(7), 31-53. DOI: https://doi.org/10.17828/yasbed.49556

Ozel, H. A. (2012). Ekonomik Büyümenin Teorik Temelleri, Cankiri Karatekin Üniversitesi iktisadi ve Idari Bilimler Fakültesi Dergisi, 2(1), 63-72.

Peter, A., \& Bakari, I. H. (2018). Impact of Population Growth on Economic Growth in Africa: A Dynamic Panel Data Approach (1980-2015), Pakistan Journal of Humanities and Social Sciences, 6(4), 412-427. DOI: http://dx.doi.org/10.2139/ssrn.3432263

Polat, M. A. (2018). Türkiye'de Ekonomik Büyümenin ve Nüfus Artisinin Ekonometrik Modellemesi: Ampirik Bir Calisma Ornegi, Agri ibrahim Cecen Üniversitesi Sosyal Bilimler Enstitüsü Dergisi, 4(1), 205-228.

Savas, B. (2008). The Relationship between Population and Economic Growth: Empirical Evidence from the Central Asian Economies, Orta Asya ve Kafkasya Arastirmalari, 3(6), 161-183.

Schwert, G. W. (1989). Tests for Unit Roots: A Monte Carlo Investigation, Journal of Business \& Economic Statistics, 7(2), 147-159. DOI: https://doi.org/10.2307/1391432

Skousen, M. (2003). Iktisadi Düsünce Tarihi: Modern iktisadin Insasi, (Translator: Mustafa Acar, Ekrem Erdem \& Metin Toprak), 7. Baski, Ankara: Adres Yayinlari.

Simsek, S. A., \& Atalay, E. (2020). Türkiye Nüfus Politikalarina Genel Bakis, Turkish Studies Social Sciences, 15(7), 41-51. DOI: http://dx.doi.org/10.47356/TurkishStudies.47227 
Taban, S., \& Kar, M. (2014). Kalkinma Ekonomisi, Bursa: Ekin Yayinevi.

Tari, R., Koc, S., \& Abasiz, T. (2019). Ekonometri, 14. Baski, Kocaeli: Umuttepe Yayinlari.

Telater, O. M., \& Terzi, H. (2010). Nüfus ve Egitimin Ekonomik Büyümeye Etkisi: Türkiye Üzerine Bir İnceleme, Atatürk Üniversitesi Iktisadi ve Idari Bilimler Dergisi, 24(2), 197214.

Thornton, J. (2001). Population Growth and Economic Growth: Long-Run Evidence from Latin America, Southern Economic Journal, 68(2), 464-468. DOI: https://doi.org/10.2307/1061606

Thuku, G. K., Paul, G., \& Almadi, O. (2013). The Impact of Population Change on Economic Growth in Kenya, International Journal of Economics \& Management Sciences, 2(6), 43-60. DOI: 10.4172/2162-6359.1000137

Toda, H. Y., \& Yamamoto, T. (1995). Statistical Inference in Vector Autoregressions with Possibly Integrated Processes, Journal of Econometrics, 66, 225-250. DOI: https://doi.org/10.1016/0304-4076(94)01616-8

Topal, K. (2011). Cevre Sorunlarinin Kaynagi Olarak Nüfus Artisi Mi? Tüketim Mi? NeoMalthusyen Düsünceye Elestirel Bir Yaklasim, Türk Idare Dergisi, 470, 133-152.

Tsen, W. H., \& Furuoka, F. (2005). The Relationship between Population and Economic Growth in Asian Economies, ASEAN Economic Bulletin, 22(3), 314-330.

Yanardag, M. O., \& Ozgen, Ü. (2003). Nüfus Kavrami ve Türkiye'de Nüfusun Gelisim Sürecininin Degerlendirilmesi, Mevzuat Dergisi, Yil: 6, Sayi: 66.

Yao, W., Kinugasa, T., \& Hamori, S. (2013). An Empirical Analysis of the Relationship between Economic Development and Population Growth in China, Applied Economics, 45(33), 4651-4661. DOI: https://doi.org/10.1080/00036846.2013.795284

World Bank. (2021). https://data.worldbank.org/ (Accessed: 03.09.2021).

https://www.statista.com/statistics/624913/singapore-population-by-age-group/ (Accessed: 21.10.2021).

https://www.heritage.org/index/country/singapore (Accessed: 15.11.2021).

https://www.fn.no/Land/singapore (Accessed: 15.11.2021).

https://www.un.org/en/global-issues/population (Accessed: 16.11.2021).

http://www.geotema.dk/leksikon/verdens-lande/asien/singapore (Accessed: 16.11.2021).

https://worldpopulationreview.com/country-rankings/countries-by-density

(Accessed: 18.11.2021).

https://stats.oecd.org/glossary/detail.asp?ID=6639 (Accessed: 25.12 .2021 ). 